\title{
ANALISIS KEAUTENTIKAN DAN KEUNIKAN LAKSA CIHIDEUNG SEBAGAI KULINER UNGGULAN KOTA BOGOR
}

\author{
Heni Pridia Rukmini Sari \\ Institut Ilmu Sosial dan Manajemen Stiami \\ email: heni.pridia@yahoo.com
}

\begin{abstract}
Abstrak. Tujuan dari penelitian ini adalah untuk mempelajari keaslian dan keunikan Laksa Cihideung sebagai kuliner khas. Penelitian ini berfokus pada keaslian makanan dan keunikan yang didefinisikan sebagai keaslian dan asli Laksa Cihideung dalam berbagai aspek. Ini adalah elemen penting dalam menggambarkan identitas, budaya, dan warisan Laksa Cihideung.

Metodologi penelitian yang digunakan dalam penelitian ini adalah deskriptif. Jumlah 35 kuesioner menurut klaster dan simple random sampling diisi oleh peserta. Oleh karena itu, wawancara mendalam dilakukan secara individual di antara pakar makanan dan peserta kuesioner untuk mencari bagaimana mereka menafsirkan makna dan karakteristik keaslian dan keunikan Laksa Cihideung yang mempengaruhi rasa makanan.

Data yang dikumpulkan melalui kuesioner dianalisis melalui SPSS 20.0. Berdasarkan temuan penelitian ini, Laksa Cihideung memiliki pengaruh besar dalam menarik wisatawan ke tujuan dari keaslian dan keunikannya.
\end{abstract}

Kata Kunci: Makanan, restoran lokal, Bogor, keaslian, keunikan, dan wisata kuliner.

Abstract. The purpose of this research was studying authenticity and uniqueness of Laksa Cihideung as distinctive culinary. This research focuses on the food authenticity and unique that is defined as the originality and genuine of Laksa Cihideung in various aspects. It is an important element in portraying the identity, culture, and heritage of Laksa Cihideung.

The research methodology employed in the present research was descriptive. The number of 35 questionnaires according to cluster and simple random sampling was filled out by participants. Hence, in-depth interviews were individually conducted among the food experts and questionnaire participants to seek how they interpret the meaning and characteristics of authenticity and uniqueness in Laksa Cihideung that influenced the taste of the food.

The data gathered through the questionnaire were analyzed via SPSS 20.0. Based on the findings of this research, Laksa Cihideung has a great influence on attracting tourists to a destination from its authenticity and uniqueness.

Key words: Food, local restaurant, Bogor, authenticity, uniqueness, and food tourism.

\section{PENDAHULUAN}

Pariwisata sebagai industri merupakan bidang yang kompleks dan keberadaannya peka terhadap perkembangan terutama yang berkaitan dengan motivasi wisatawan yang selalu ingin menikmati pengalaman baru. Wisata kuliner yang dapat diartikan sebagai suatu pencarian akan pengalaman kuliner yang unik dan selalu terkenang dengan beragam jenis makanan sering diminati dalam setiap perjalanan wisata. Menurut Global Report and Food Tourism (2012), wisata kuliner adalah segmen industri kuliner yang sedang berkembang pesat, oleh karenanya, pelaku industri wisata di setiap negara harus memahami pentingnya perkembangan wisata kuliner dalam skala lokal, regional, dan nasional (UNWTO, 2012). Di sisi lain, kuliner memegang peranan penting dalam meningkatkan daya tarik wisata; meningkatkan jumlah wisatawan; meningkatkan pengalaman wisatawan; memperkuat identitas daerah; dan stimulasi pertumbuhan sektor lainnya. Sangat jelas 
Heni Pridia Rukmini Sari, Analisis Keautentikan dan Keunikan Laksa Cihideung Sebagai ...

bahwa kuliner menyumbang pengaruh berkesinambungan terhadap tujuan wisata. (Steinmetz, 2010:9).

Sebagai negara dengan beragam pilihan destinasi wisata yang menarik, Indonesia memiliki potensi besar dalam mengembangkan wisata kuliner di tiap daerah. Keragaman budaya di Indonesia ini melahirkan kuliner yang beraneka dan khas, yang bisa menjadi daya tarik bagi wisatawan. Belakangan, wisatawan tak lagi segan blusukan meski ke pelosok negeri sekalipun, hanya untuk mencicipi suatu hidangan unik. Dari aneka nasi yang menjadi makanan wajib orang Indonesia, beragam sayur dan lauk pauk, hingga aneka camilan dan minuman. Seperti dikatakan oleh Erik Wolf (2014) dari World Food Travel Association, wisata kuliner adalah mengejar dan menikmati pengalaman makan dan minum yang unik dan berkesan, di tempat jauh maupun dekat. Inskeep (1991), menyatakan bahwa makanan lokal merefleksikan sejarah dan budaya dari suatu wilayah dan bisa menjadi atraksi yang menarik bagi wisatawan. Dalam upaya memberikan nilai tambah bagi wisatawan, diperlukan juga usaha untuk mempromosikan makanan lokal yang unik, sehingga wisatawan berkeinginan untuk mencicipi salah satu jenis makanan lokal.

Menyikapi berbagai pergeseran, perubahan, dan perkembangan industri pariwisata, mulai tahun 2011 Kementerian Pariwisata dan Ekonomi Kreatif (Kemenparekraf) menjadikan wisata kuliner sebagai bagian dari ekonomi kreatif. Harapannya tentu saja mampu menarik jumlah wisatawan. Dalam kaitan wisata kuliner dan belanja sebagai bagian dari wisata minat khusus, Kemenparekraf kini memetakan kuliner yang menjadi unggulan masing-masing provinsi. Kuliner unggulan adalah suatu produk makanan yang dinilai lebih dari produk makanan lainnya. Kuliner unggulan ini juga mempunyai keunggulan baik dari sisi produksi, kontinyuitas, dan daya saing sehingga diterima masyarakat dan menarik investor. Kuliner unggulan daerah selain merupakan wujud dari karakteristik dan ragam produk juga merupakan media untuk berkomunikasi dengan dunia luar Untuk itu
Kemenparekraf mengkaji standardisasi masakan Indonesia agar kualitas cita rasa kuliner Indonesia tetap terjaga. (Anonim, 2014).

Laksa di Indonesia merupakan hidangan sepinggan akulturasi antara makanan Cina dan makanan lokal setempat. Seporsi laksa terdiri atas bihun dengan ketupat, taoge, tahu, dan ditambahkan kuah santan kental. Dikatakan oleh Sidharta (2008), "Pelaut Cina yang datang ke Nusantara tidak mengajak istri mereka. Oleh sebab itu pelaut tersebut akhirnya menikah dengan wanita setempat. Akibat dari pernikahan tersebut terjadi percampuran antara budaya memasak Cina dengan bahan-bahan lokal seperti penggunaan cabai sehingga cita rasa masakan menjadi lebih pedas dan santan. Sehingga akhirnya tercipta yang dinamakan sebagai laksa." Belum ada yang literatur yang mengatakan dari mana asal kata laksa yang sebenarnya. Satu teori mengatakan bahwa kata laksa berasal dari Cina, yaitu dari bahasa Kanton liet'sa yang artinya pasir berbumbu. Hal ini karena ke dalam kuah laksa dicampurkan dengan ebi bubuk yang teksturnya seperti butiran pasir kasar. Teori lainnya menyatakan bahwa laksa berasal dari bahasa India lakshah yang artinya bihun (Winarno, 2013:94).

Laksa memang terkenal sebagai makanan kebanggaan Malaysia. Di negeri jiran tersebut, laksa terbagi atas dua varian, yaitu laksa lemak yang merupakan laksa dengan kuah santan, dan laksa dengan kuah dari kaldu ikan. Di Indonesia, laksa bisa ditemukan di wilayah dengan kebudayaan Melayu yang kental, seperti Riau, Bangka, dan Belitung. Namun, laksa juga bisa ditemukan di Jakarta, Tangerang, dan Bogor (Winarno, 2013:94). Di Bogor, laksa termasuk makanan yang populer. Penjualnya tersebar di beberapa wilayah, seperti di Gang Aut, Jl. Ranggagading, dan J1. Suryakencana yang merupakan destinasi wisata utama di Bogor, hingga ke Cihideung di perbatasan antara Bogor dan Sukabumi (Soegiarto, wawancara, 28 Januari 2015). Berdasarkan observasi yang dilakukan peneliti, salah satu penjual laksa yang digemari oleh berbagai pengunjung ataupun wisatawan domestik adalah Laksa Cihideung yang didirikan oleh 


\section{TRANSPARANSI}

Jurnal Ilmiah Ilmu Administrasi

ISSN 2085-1162

Inin sejak tahun 1963. Ia termasuk satu sentra penjualan laksa yang paling kerap didatangi pengunjung, bukan saja oleh wisatawan dari seputar Bogor, tetapi juga dari luar kota Bogor.

Berdasarkan uraian terdahulu, masalah Penelitian dapat digambarkan dalam Problem Tree sebagai berikut:

a. Bagaimana ke"khas"an (authenticity) Laksa Cihideung (bahan dasar, resep khas, cara membuat, dan cita rasa) untuk menjadi makanan/kuliner unggulan kota Bogor?

b. Bagaimana "uniqueness" (sejarah, budaya) Laksa Cihideung untuk menjadi representasi kuliner unggulan kota Bogor?

\section{KERANGKA TEORITIS}

Menurut Hall \& Mitchell (2002) wisata kuliner (food tourism) secara umum dapat didefinisikan sebagai kunjungan ke produsen makanan, festival makanan, restoran dan lokasi spesifik untuk mencicipi makanan dan/atau menikmati/mempelajari produksinya. Dengan demikian makanan, produksi makanan dan atribut khusus makanan daerah menjadi dasar dan faktor pendorong utama dalam perjalanan wisata. Bahkan satu penelitian mengatakan bahwa wisatawan menghabiskan $40 \%$ dari pengeluaran mereka untuk makanan. Begitu juga dengan survei yang dilakukan oleh The 2004 Restaurant \& Food Service Market Research Handbook bahwa 50\% pendapatan dari suatu restoran berasal dari wisatawan (Boyne, Williams, \& Hall, 2002).

Sedangkan Long (2003) mengatakan bahwa wisata kuliner adalah pengalaman dari seseorang saat mencicipi suatu makanan. Pengalaman berwisata kuliner tidak terbatas hanya soal mencicipi makanan saja, tapi juga dalam hal persiapan dan penyajian suatu makanan. Long juga menekankan bahwa cita rasa makanan merupakan hal utama yang bisa memberi pengalaman unik dan berkesan bagi wisatawan. Lain lagi dengan Hall dan Sharples (2003) yang menguraikan tentang food tourism ini, yaitu kegiatan berkunjung di
Volume 9, Nomor 02, September 2017

restoran/tempat makan saat berwisata, festival makanan lokal karena berbeda, sebagai wujud adanya kebutuhan makan minum selama berwisata. Ketertarikan terhadap makanan lokal tergolong rendah, karena tujuan utamanya bukan menikmati makanan lokal melainkan berwisata.

Menurut Undang-Undang RI No. 10 Tahun 2009 tentang kepariwisataan, wisatawan adalah orang yang melakukan perjalanan wisata. Selain pemahaman soal wisatawan sebagai orang yang melakukan perjalanan wisata, wisatawan juga dapat dikelompokkan atas berbagai dasar, yaitu atas dasar interaksi (interaction type) dan kognitifnormatif (cognitive-normative models). Pada tipologi dasar interaksi ditekankan pada sifatsifat interaksi antara wisatawan dengan masyarakat lokal. Sedangkan pada tipologi kognitif-normatif ditekankan pada motivasi yang melatarbelakangi suatu perjalanan wisata (Pitana, 2009). Dapat disimpulkan bahwa wisatawan yang melakukan perjalanan wisata pada umumnya ingin mencari sesuatu yang baru di daerah tujuan wisata, berinteraksi dan belajar budaya lokal dan dapat menerima fasilitas yang ada.

Sedangkan menurut Wahab (2007: 5) ada beberapa faktor yang mempengaruhi wisatawan untuk melakukan perjalanan ke suatu destinasi, yaitu:

a. Faktor internal bergantung pada citra yang dimiliki wisatawan tentang suatu daerah tujuan wisata, mulai dari pelayanan yang diberikan, daya tarik daerah tujuan wisata, harga, keamanan dan ketertiban, serta harapan yang ingin dicapai oleh wisatawan.

b. Faktor eksternal sebagai faktor luar seperti informasi yang disampaikan dan promosi yang diberikan selama proses pengambilan keputusan memilih daerah tujuan wisata.

Adapun destinasi pariwisata adalah suatu entitas yang mencakup wilayah geografis tertentu yang di dalamnya terdapat komponen produk pariwisata (attractions, amenities, accessibilities) dan layanan serta unsur pendukung lainnya (masyarakat, pelaku 
Heni Pridia Rukmini Sari, Analisis Keautentikan dan Keunikan Laksa Cihideung Sebagai ...

industri pariwisata, dan institusi pengembang) yang membentuk sistem yang sinergis dalam menciptakan motivasi kunjungan serta kualitas pengalaman kunjungan bagi wisatawan. Ahli merumuskan konsep destinasi wisata ini secara berbeda namun dengan substansi yang memiliki kesamaan. Seperti dikatakan Hu \& Ritchie (1993: 26) yang merumuskan destinasi wisata secara konsepsional sebagai satu paket fasilitas dan pelayanan bagi wisatawan dengan banyak aspek yang tercakup di dalamnya. Konsep ini menegaskan bahwa suatu destinasi bersifat multidimensional yang ditandai oleh banyaknya atribut yang melekat pada destinasi tersebut.

Sedangkan oleh UNWTO (2012), destinasi wisata dijelaskan sebagai sebuah tempat dimana wisatawan akan menginap paling tidak selama satu malam. Di dalamnya terdapat daya tarik wisata, fasilitas pendukung, dan sumber daya. UNWTO (2012) juga menyatakan dalam A Practical Guide to Tourism Destination Management bahwa suatu destinasi wisata harus memiliki elemen-elemen dasar yang meliputi attractions, public and private amenities, accessibility, human resources, image and character, serta price. Semua unsur tersebut saling tergantung satu sama lain karena semua aspek tersebut dibutuhkan oleh wisatawan selama mengunjungi suatu destinasi wisata. Aspek-aspek yang sengaja dibuat di suatu destinasi wisata yang berbeda dari yang sudah menjadi keunikan dari destinasi wisata tersebut. Pemasaran yang harus bisa mempromosikan suatu daerah tujuan wisata.

Inskeep (1991) menyatakan bahwa makanan lokal merefleksikan sejarah dan budaya dari suatu wilayah. Karena adanya keunikan, makanan lokal bisa menarik perhatian wisatawan untuk mencicipinya. Selain itu, Au \& Law (2002) juga menyatakan bahwa ada hubungan yang erat antara kuliner dan pariwisata. Setiap daerah punya tingkat kemenarikan yang berbeda bagi setiap wisatawan. Makanan yang autentik dan juga unik bisa menjadi faktor yang menarik bagi wisatawan untuk mendatanginya. Indonesia, seperti diungkapkan oleh Murdijati (2014) memiliki kekayaan biodiversity nomor dua di dunia setelah Brasil. Ada 17 macam sumber karbohidrat, 171 macam sayuran, 300 jenis buah, dan 50 varian bumbu. Inilah sebenarnya yang menjadi satu potensi besar bagi Indonesia untuk menjual keunikannya terutama soal kuliner. Seperti dikatakan oleh Kolar \& Zabkar (2010), aspek autentik merupakan faktor yang berperan dalam strategi pemasaran suatu produk.

Menurut Bromokusumo, budaya Nusantara banyak sekali dipengaruhi oleh budaya kuliner Tionghoa. Pengaruh dari kebudayaan asing ini kuat mengakar dan bertansformasi menjadi salah satu identitas yang baru sama sekali. Kuliner Indonesia hasil akulturasi dengan budaya Tionghoa ini menemukan bentuknya sendiri yang tidak dapat ditemui di dapur Tiongkok (2013: xxi). Kuliner yang dihasilkan adalah kuliner yang sama sekali baru dan spesifik khas Nusantara. Kemudian dalam perjalanannya, kuliner "baru" ini juga diadopsi oleh negara tetangga seperti Malaysia dan belakangan Singapura yang memiliki kesamaan dan kemiripan demografis (2013: 3). Seperti laksa yang merupakan makanan populer dalam dapur peranakan. Sebetulnya, laksa dikenal sebagai makanan akulturasi antara makanan Cina dan makanan Melayu. Laksa bisa ditemukan di Indonesia, Malaysia, dan Singapura. CNN Travel bahkan pernah menobatkan laksa di peringkat ke-7 dari 50 makanan paling lezat sedunia (Anonim, 2011).

Ada tiga jenis laksa, yaitu laksa kari, asam laksa, dan yang bukan termasuk laksa kari dan asam laksa. Laksa kari berisi mi atau bihun sebagai bahan utama dan ditambahkan dengan tahu atau bakso ikan. Yang menjadi ciri utama dari laksa kari ini adalah kuah santan dengan bumbu kari yang kental. Warna kuahnya pun kuning. Sayuran yang dimasukkan ke dalam laksa kari umumnya adalah taoge. Laksa kari populer di wilayah Malaysia dan Singapura. Sedangkan asam laksa berkuah jernih karena terbuat dari kaldu ikan dan bercita rasa asam. Oleh CNN Go di tahun 2011 ini, asam laksa pernah dinobatkan di peringkat ke-7 dari 50 makanan terlezat dunia. Bahan utama pembuat asam laksa ini adalah ikan (kembung atau tongkol) yang direbus untuk mendapatkan kaldunya bersama 


\section{TRANSPARANSI}

Jurnal Ilmiah Ilmu Administrasi

ISSN 2085-1162

dengan asam. Asam yang dipakai bisa asam jawa atau asam gelugur. Selain itu ke dalam seporsi laksa juga ditambahkan dengan mi dan sayuran (daun kesum atau bunga kecombrang). Asam laksa populer di wilayah Malaysia.

Selain kedua macam laksa tersebut adapula di Indonesia juga terdapat laksa di Bangka, Belitung, Tangerang, Bogor, dan Jakarta). Umumnya, berisi bihun dengan kuah santan kental dan kondimen lainnya seperti ketupat, oncom, daun kemangi, taoge, dan tahu. Di Bogor, laksa merupakan satu makanan yang populer. Kini penjualnya terkonsentrasi di beberapa tempat, seperti di Gang Aut, Jl. Suryakencana, Jl. Ranggagading, dan Cihideung. Komposisi bahan Laksa Cihideung yang dijajakan secara berkeliling adalah adanya tambahan oncom merah. Kuah Laksa Cihideung berupa santan yang dimasak hingga kental dengan warna kekuningan. Bumbu laksa terdiri atas bawang merah, bawang putih, kemiri, kunyit, jahe, ketumbar, serai, temu mangga, merica, garam, dan daun salam. Saat hendak disajikan, bihun, taoge, oncom, dan kemangi harus diseduh dengan kuah laksa panas secara berulangulang. Tujuannya untuk mematangkan bahanbahan tersebut. Setelahnya, dimasukkan ke dalam piring saji dan ditambahkan dengan ketupat, tahu yang direbus dalam kuah santan, dan serundeng. Atau, jika ingin lebih komplet bisa ditambahkan dengan telur ayam rebus atau daging ayam suwir. Pelengkap lainnya adalah sambal cuka.

\section{METODOLOGI PENELITIAN}

Menurut Kusmayadi (2000) penelitian adalah proses berpikir secara logis dan analitis untuk menghasilkan kesimpulan yang benar. Sedangkan metode penelitian deskriptif adalah metode penelitian yang melukiskan secara sistematis fakta atau karakteristik populasi tertentu atau bidang tertentu. Metode penelitian deskriptif dapat diartikan sebagai prosedur pemecahan masalah yang diselidiki dengan menggambarkan atau melukiskan keadaan subjek atau objek penelitian pada saat sekarang berdasarkan fakta-fakta itu pada
Volume 9, Nomor 02, September 2017

tahap permulaan tertuju pada usaha mengemukakan gejala-gejala secara lengkap di dalam aspek yang diselidiki agar jelas keadaan dan kondisinya. Pada tahap berikutnya dikembangkan dengan memberikan penafsiran yang memadai atas fakta-fakta yang ditemukan. Metode ini pada dasarnya dapat diwujudkan juga sebagai usaha memecahkan masalah dengan membandingkan persamaan dan perbedaan gejala yang ditemukan, mengadakan klasifikasi gejala, menilai gejala, menetapkan hubungan antar gejala yang ditemukan, dan lain-lain. Secara singkat dapat dikatakan bahwa metode deskriptif ini merupakan langkah melakukan representasi objektif tentang gejala yang terdapat di dalam masalah yang diteliti. (Nawawi, 1991).

Sedangkan Nazir (1999) menyatakan bahwa metode deskriptif adalah suatu metode untuk meneliti status sekelompok manusia, suatu objek, suatu set kondisi, suatu sistem pemikiran ataupun suatu kelas peristiwa pada masa sekarang. Tujuan dari penelitian deskriptif ini adalah untuk membuat deskripsi, gambaran, atau lukisan secara sistematis, faktual dan akurat mengenai faktafakta, sifat-sifat serta hubungan antara fenomena yang diselidiki. Dijelaskan juga oleh Shields \& Tajalli (2006) bahwa ada hubungan yang erat antara kerangka teoritis, masalah penelitian, dan data-data yang akan dianalisis. Saat masalah penelitian ditemukan, peneliti harus menganalisis literatur untuk menemukan jawaban dengan menggunakan teori yang sesuai. Penelitian ini bertujuan untuk memperoleh gambaran mengenai Laksa Cihideung sebagai kuliner khas di Bogor. Hal ini dilakukan dengan mengukur variabelvariabel yang berhubungan dengan faktorfaktor yang mempengaruhinya.

Unit yang akan diteliti dalam penelitian ini adalah Laksa Cihideung yang berada di perbatasan antara Bogor dan Sukabumi di wilayah Provinsi Jawa Barat. Wisatawan yang datang ke Laksa Cihideung adalah sebagai subjek yang akan menentukan untuk memberikan penilaian terhadap variabelvariabel yang memberikan gambaran Laksa 
Heni Pridia Rukmini Sari, Analisis Keautentikan dan Keunikan Laksa Cihideung Sebagai ...

Cihideung sebagai kuliner unggulan kota Bogor. Dengan demikian sampel dalam penelitian ini adalah wisatawan yang datang berkunjung ke Laksa Cihideung. Penelitian ini bertujuan untuk mencari tahu faktor keautentikan dan keunikan Laksa Cihideung sebagai kuliner unggulan di kota Bogor. Penelitian dilakukan di Laksa Cihideung milik Inin. Pengumpulan data dilakukan pada Januari hingga Juli 2015.

Laksa Cihideung dipilih karena berdasarkan observasi awal yang dilakukan oleh peneliti diketahui bahwa jumlah pengunjung yang datang ke Laksa Cihideung pada hari kerja berkisar rata-rata 150 orang sedangkan pada akhir pekan berkisar 300 orang. Laksa Cihideung juga tetap bertahan hingga sekarang meskipun telah didirikan sejak tahun 1963 dan kini dijalankan oleh generasi keduanya. Selain itu, penggunaan kayu sebagai bahan bakar pengolahan laksa yang membuat Laksa Cihideung menjadi unik. Namun belum diketahui faktor apa yang membuat Laksa Cihideung bisa dijadikan sebagai kuliner unggulan kota Bogor. Untuk mendapatkan bukti dan keakuratan penelitian, dalam pelaksanaannya penelitian ini dilibatkan beberapa pihak sebagai informan, yaitu pemilik Laksa Cihideung, Didin yang merupakan anak dari almarhum Inin, pendiri Laksa Cihideung, ahli yang merupakan pengamat kuliner kota Bogor, dan wisatawan yang merupakan pengunjung Laksa Cihideung.

Sebelum melakukan penarikan sampel akan dilakukan terlebih dahulu penentuan populasi. Menurut Easton \& Mc Coll (1997) dikatakan bahwa "A population is any entire collection of people, animals, plants, or things from which we may collect data. It is the entire group we are interested in, which we wish to describe or draw conclusions." Populasi yang diteliti adalah wisatawan yang berkunjung ke Laksa Cihideung. Penarikan sampel dilakukan dengan 6 langkah dalam prosedur penarikan sampel, yaitu (1) menentukan populasi, (2) menentukan kerangka sampel, (3) memilih metode sampel, (4) menentukan ukuran sampel, memutuskan rencana sampel, (6) mengumpulkan sampel. Pemilihan sampel dalam penelitian ini menggunakan rumus yang dikembangkan oleh Slovin. Metode sampling dari Slovin ini biasanya dilakukan oleh peneliti agar dapat menghemat biaya penelitian secara lebih efektif. Yang harus diperhatikan saat menggunakan metode ini adalah batas toleransi kesalahan yang dinyatakan dengan persentase. Makin kecil toleransi kesalahan, sampel akan makin akurat dalam menggambarkan populasi. Jika populasi Laksa Cihideung sebanyak 300 wisatawan per hari pada akhir pekan dengan error tolerance yang dipakai adalah 5\%. Maka besarnya jumlah sampel yang dibutuhkan adalah $\mathrm{n}=300 / 1+300 \times 0,052=35$ wisatawan.

Teknik pengumpulan data merupakan salah satu aspek yang berperan dalam kelancaran dan keberhasilan suatu penelitian. Dalam penelitian ini data yang dibutuhkan adalah:

a. Data primer yaitu jenis data yang langsung diambil dari sumber asli atau pertama, yaitu wisatawan yang berkunjung ke Laksa Cihideung. Ada tiga cara pengumpulan data primer yaitu observasi lapangan, wawancara, dan kuesioner.

b. Data sekunder adalah jenis data yang diperoleh dari sumber buku, internet, serta beberapa instansi yang berkaitan dengan kepentingan penelitian ini. Dikatakan oleh Kusmayadi (2000) bahwa data sekunder berupa jurnal, makalah, hasil penelitian lain, publikasi dari media, laporan instansi pemerintah dan lembaga pemerintah, serta peraturan atau kebijakan yang berkaitan dengan sektor pariwisata. Cara memperoleh data sekunder adalah dengan studi pustaka/literature dan dokumen yang terkait dengan masalah yang diteliti. Data sekunder yang dicari adalah data yang berhubungan dengan Laksa Cihideung.

\section{ANALISIS DAN PEMBAHASAN}

\section{a. Profil Warung Laksa Cihideung}

Warung Laksa Cihideung milik Pak Inin terletak di Bogor bagian selatan, yaitu di Jalan Raya Cihideung, Kampung Cijeruk, Desa Palasari, RT 02 RW 02, Cijeruk Bogor. 


\section{TRANSPARANSI}

Jurnal Ilmiah Ilmu Administrasi

ISSN 2085-1162

Warung ini berada di jalur alternatif yang menghubungkan Bogor dengan Sukabumi. Warung terletak sekitar 10 kilometer dari pusat kota Bogor dan jalan paling nyaman untuk menuju ke warung ini adalah melalui daerah Batutulis. Jalan raya di depan warung laksa ramai dengan kendaraan pribadi atau angkutan umum karena jalur ini merupakan jalan alternatif menuju ke Sukabumi. Jalur ini merupakan jalan bypass untuk menghindari kemacetan di Ciawi.

Warung Laksa Cihideung didirikan oleh Pak Inin pada tahun 1963. Sebelum menetap di tempat yang sekarang, Pak Inin berjualan dengan pikulan di daerah Gang Aut di Bogor Kota. Karena akhirnya menetap di daerah Cihideung, Pak Inin beralih wilayah berjualan menjadi di seputaran Cihideung. Itu pun masih berjualan dengan cara dipikul keluar masuk kampung hingga tahun 1990-an. Karena makin tua, Pak Inin lalu memutuskan untuk berhenti berjualan dengan cara keliling kampung, tapi dengan menetap di satu tempat. Dipilihlah tempat di pos ronda yang terletak di depan rumahnya. Walau perlahan, jualan Pak Inin mulai mempunyai banyak pembeli. Dari tetangga sekitar dan juga dari orang yang melintas di depan warung. Warung yang semula hanya sebesar pos ronda untuk tempat menaruh pikulan laksa dengan dilengkapi satu meja berukuran 80x120 cm dan dua buah bangku bakso kemudian diperbesar hingga berukuran 4x6 meter dengan dinding anyaman bambu dan lantai tanah.

Di dalam warung terdapat dua buah meja berukuran 80x120 cm dengan masing-masing dua buah bangku kayu dengan panjang 120 $\mathrm{cm}$ dan tiga buah balai-balai dari bambu berukuran 160x160 cm. Sebagai penanda warung laksa, di bagian depan warung terletak pikulan Pak Inin untuk tempat laksa diracik. Pikulan laksa mempunyai ciri khas, yaitu berwarna merah dan kuning sehingga tampil mencolok mata saat dulunya dijajakan keliling kampung. Pada masa kini pun meski tidak dijajakan keliling, pikulan ini masih mencolok mata. Dulu, selain warna pikulan, tempat menaruh kuah laksa juga khas.
Terbuat dari gentong tanah liat dan dimasak dengan menggunakan kayu bakar. Kini sesuai dengan perkembangan zaman, gentong tanah liat di warung laksa Pak Inin sudah diganti dengan panci dari stainless steel. Namun bahan bakarnya tetap menggunakan kayu yang diambil dari kayu-kayu bekas di sekitar tempat tinggal di Kampung Cijeruk. Hasilnya, saat dicicipi, laksa menjadi lebih harum karena ada aroma kayu bakarnya.

Pak Inin meninggal pada tahun 2012 dan penjualan laksa diteruskan oleh anaknya Didin. Waktu buka warung adalah mulai pukul 08.00 WIB hingga pukul 15.00 WIB kecuali jika laksa sudah habis sebelum pukul 3 sore, warung laksa akan tutup lebih cepat dan setiap hari Jumat warung Laksa Cihideung tutup sesuai dengan kebiasaan Inin sejak menjajakan laksa pertama kali pada tahun 1963. Alasannya karena hari Jumat adalah waktu untuk beribadah. Kutipan wawancara dengan Didin (38 tahun), pemilik Laksa Cihideung: "Bapak mah dahulu jualan mulai pagi-pagi. Jam 8 dagangan sudah siap. Tutupnya sehabisnya. Bisa jam 3 atau malah sebelumnya kalau memang sudah habis duluan. Jumat libur karena harus sholat Jumat."

Pada hari kerja, jumlah pengunjung yang datang rata-rata berkisar 150 orang berdasarkan observasi langsung oleh peneliti, yang kebanyakan merupakan pelintas yang lewat di depan warung saat menuju tempat kerja dan rombongan pekerja. Sedangkan pada akhir pekan, pengunjung yang datang menjadi dua kali lipatnya, sekitar 300 orang, yang terdiri atas keluarga, komunitas pesepeda, atau beberapa keluarga yang berpergian bersama. Wisatawan yang datang tampak makan di tempat atau mampir membeli laksa untuk disantap di rumah. Seporsi laksa harganya Rp9.000 dengan isi berupa ketupat, bihun, taoge, oncom, tahu, kemangi, dan serundeng yang disiram oleh kuah laksa yang berwarna kuning. Sebagai tambahan protein hewani ditaruh sebutir telur ayam rebus.

Di hari kerja, warung Laksa Cihideung menghabiskan 150 buah ketupat, $5,25 \mathrm{~kg}$ 
Heni Pridia Rukmini Sari, Analisis Keautentikan dan Keunikan Laksa Cihideung Sebagai ...

taoge, $5,25 \mathrm{~kg}$ bihun, 150 buah tahu kuning, $5,25 \mathrm{~kg}$ oncom, 90 ikat @ 10 tangkai kemangi, $3 \mathrm{~kg}$ serundeng, dan 150 butir telur ayam. Kuah laksa yang dibuat setiap hari adalah sebanyak 37,5 L. Sedangkan pada akhir pekan, bahan-bahan yang disiapkan menjadi dua kali lipat jumlahnya dari hari kerja. Semua bahan-bahan yang digunakan dibeli Didin di pasar tradisional di daerah Bogor. Semua bahan ini selalu dibeli setiap hari untuk menjaga kualitas laksa yang dihasilkan, yaitu:

a. Ketupat yang digunakan dibeli sudah dalam keadaan siap saji. Sehingga saat diracik di warung, ketupat tinggal dipotong-potong untuk dimasukkan ke dalam piring saji. Ketupat dibeli di pasar tradisional di Pasar Cijeruk.

b. Taoge yang digunakan adalah taoge lokal yang dibeli di pasar tradisional di daerah Cijeruk. Sebelum diseduh, taoge dicuci bersih untuk menghilangkan kotorannya.

c. Bihun juga dibeli di pasar tradisional di Cijeruk. Merek yang digunakan adalah AAA. Bihun harus diseduh dulu dengan air mendidih hingga lunak, ditiriskan, dan bisa digunakan sebagai campuran laksa.

d. Tahu yang digunakan adalah tahu Bogor yang berwarna kuning. Tahu direbus di dalam kuah santan hingga matang. Tahu dibeli di pasar tradisional di Cijeruk.

e. Oncom yang digunakan adalah oncom merah yang berasal dari ampas tahu. Oncom dibeli di pasar tradisional di Cijeruk.

f. Kemangi juga dibeli di pasar tradisional di Cijeruk. Sebelum digunakan, kemangi dicuci bersih dan disiangi untuk menghilangkan kotorannya.

g. Untuk kuah laksa terdiri atas santan, kelapa parut, dan bumbu halus. Santan yang dipakai dari buah kelapa utuh yang diparut di pasar lalu diperas di rumah hingga keluar santannya. Kelapa dibeli di pasar tradisional di Cijeruk. Ampas kelapa parut yang dimasukkan ke dalam kuah santan diambil dari sisa kelapa parut untuk membuat santan. Kelapa parut diambil sebanyak 100 gram dan dimasukkan saat santan sudah hampir mendidih. Kelapa parut ini membuat tekstur kuah laksa menjadi lebih berampas.

Bumbu untuk kuah laksa yang berwarna kuning terdiri atas rempah segar, yaitu daun salam dan serai serta bumbu yang dihaluskan, yaitu bawang merah, bawang putih, kemiri, kunyit, ketumbar, merica, jahe, dan temu mangga. Semua rempah tersebut dibeli di pasar tradisional di Cijeruk. Yang membuat laksa menjadi khas adalah bumbu yang bernama temu mangga. Bentuknya mirip dengan kunyit, namun bagian dalamnya tidak berwarna oranye melainkan kuning muda. Aromanya yang asam segar mirip aroma mangga muda yang membuat rempah ini diberi nama temu mangga.

Selain temu mangga, kuah laksa harus berwarna kuning. Yang membuat warna kuning ini adalah rempah kunyit. Agar bumbu menjadi lebih harum dan tidak langu, bumbubumbu seperti kunyit, kemiri, dan ketumbar diberi perlakuan khusus. Kunyit harus dibakar dahulu di atas bara api, kemiri digoreng, dan ketumbar disangrai. Kutipan wawancara dengan Didin (38 tahun), pemilik Laksa Cihideung: "Resepnya sih biasa aja. Cuma Bapak kalau bikin pakai temu manga. Jadi bumbunya lebih enak. Kunyitnya juga dibakar dulu supaya wangi."

Setiap hari, Didin dan istri bekerja bergantian untuk meracik laksa di warung. Meracik laksa ini menjadi satu pertunjukan yang unik bagi pengunjung yang baru datang pertama kali. Di dalam mangkuk akan ditaruh taoge, kemangi, oncom, dan bihun seduh. Keempat bahan tersebut lalu dipanaskan secara berulang sebanyak tiga kali dengan kuah laksa untuk mematangkan bahan-bahan tersebut. Setelahnya baru diletakkan di piring saji dan ditambahkan dengan ketupat, tahu, kuah laksa, dan serundeng. Proses mematangkan keempat bahan tersebut yang bisa dijadikan sebagai satu daya tarik untuk yang belum pernah mengenal dan mencicipi Laksa Cihideung.

Laksa lalu disajikan dengan uap panas yang masih mengepul. Sebagai pelengkap laksa bisa disantap dengan sambal cabai rawit hijau dan kerupuk putih. Saat dicicipi terdeteksi cita rasa laksa yang manis karena penggunaan santan dan juga sisa kelapa parut 


\section{TRANSPARANSI}

Jurnal Ilmiah Ilmu Administrasi

ISSN 2085-1162

(ampas) yang dimasukkan ke dalam kuah laksa sehingga tekstur kuah terlihat lebih pekat. Karena cita rasa laksa yang manis, di warung disediakan teh hangat tawar untuk penyeimbang rasa manis dari kuah laksa. Tetapi, jika ingin minuman lainnya tersedia juga minuman botolan, jeruk hangat atau dingin, dan es kelapa. Sekali bersantap di warung laksa ini biasanya menghabiskan Rp 16.000 yang terdiri atas satu porsi laksa komplet (Rp 9.000), satu bungkus kerupuk putih (Rp 2.000), dan satu gelas es jeruk ( $R p$ 5.000).

Pengunjung warung laksa Pak Inin ini bervariasi. Di akhir pekan yang datang kebanyakan adalah pasangan suami istri bersama anak-anak mereka. Selain itu tampak juga beberapa keluarga yang datang bersama. Mereka mampir di warung laksa Pak Inin untuk sarapan dan kemudian melanjutkan perjalanan menuju Sukabumi atau objek wisata lain yang letaknya berdekatan dengan warung laksa ini. Sedangkan pada hari kerja, pengunjung yang datang adalah karyawan yang kebetulan melintas untuk menuju tempat kerja mereka. Pengunjung saat hari kerja bisa datang sendiri atau berdua dengan teman atau pasangan.

Selain mengandalkan pengunjung yang datang ke warung, Laksa Cihideung juga sering diminta sebagai pengisi gubuk makanan di acara-acara yang diadakan oleh pemerintah, swasta, atau perkawinan. Minimal pemesanan untuk acara-acara tersebut adalah 200 porsi laksa. Setiap ada pemesanan, pikulan laksa cadangan yang berwarna merah dan kuning akan dibawa serta untuk dipasang di booth acara. Istri Didin akan berjaga dan meracik laksa di lokasi hingga acara selesai berlangsung. Sementara di warung Laksa Cihideung, Didin yang menjadi juru racik laksa.

\section{b. Pola Konsumsi Laksa Cihideung}

Karakteristik sosial demografis sangat penting untuk memperlihatkan pola konsumsi makanan dan bisa menjadi push factor wisatawan untuk mengunjungi suatu destinasi wisata. Faktor demografis juga berpengaruh dalam hal pemilihan makanan. Yang termasuk ke dalam faktor demografis adalah jenis kelamin, usia, daerah tempat tinggal, jumlah penghasilan, tingkat pendidikan, dan daerah tempat tinggal (Verbeke \& Lo'pez, 2005). Karakteristik responden yang dominan yaitu wanita sebanyak 19 responden, berusia antara 31 hingga 40 tahun sebanyak 13 responden, dengan tingkat pendidikan sarjana (S1) sebanyak 13 responden, status menikah sebanyak 25 responden, bekerja sebagai pegawai/PNS sebanyak 13 responden, mempunyai penghasilan per bulan sebesar Rp2.000.000 hingga Rp4.000.000 sebanyak 16 responden, dan berdomisili di Bogor sebanyak 23 responden.

Terlihat bahwa status menikah merupakan faktor yang dominan dari responden yang diteliti (25 responden). Faktor pernikahan ternyata mempunyai efek tentang kebiasaan makan di luar karena pasangan yang sudah menikah menghabiskan lebih banyak uang mereka untuk makanan dan juga makan di luar. Data lainnya yang dominan adalah tingkat pendidikan. Makin tinggi tingkat pendidikan seseorang serta penghasilan yang didapat, penilaian seseorang soal makanan juga meningkat. Makanan tidak hanya sekadar untuk menuntaskan rasa lapar, tapi juga untuk menambah perbendaharaan soal cita rasa.

Usia juga berpengaruh untuk menentukan pola konsumsi seseorang. Dikatakan oleh Tse \& Crotts (2005) bahwa wisatawan dengan usia yang matang menginginkan untuk mengonsumsi makanan yang lain dari apa yang sudah mereka kenal sehari-hari. Seperti data pada Gambar 4.6 terlihat bahwa usia responden yang dominan adalah 31-40 tahun. Mengacu pada studi yang dilakukan oleh Tse \& Crotts, pada kelompok usia tersebut, responden ingin mencoba makanan yang baru yang tidak biasa mereka konsumsi secara reguler. Untuk itulah mereka menyantap Laksa Cihideung karena laksa bukan jenis makanan yang biasa dibuat di rumah. Menurut Kim et al. (2009) pola konsumsi makanan ini juga sangat terpengaruh akan gender bahwa wanita punya kecenderungan 
Heni Pridia Rukmini Sari, Analisis Keautentikan dan Keunikan Laksa Cihideung Sebagai ...

dan memang sangat tertarik untuk mencicipi cita rasa makanan yang baru di suatu daerah wisata. Seperti pada survei yang dilakukan oleh peneliti, dominasi pengisi kuesioner adalah wanita.

Dikatakan juga oleh Kim et al. (2009) bahwa makin tinggi tingkat pendidikan yang diperoleh keinginan untuk mengenal budaya lain lewat makanan lokal juga makin tinggi. Ini berkorelasi dengan hasil penelitian bahwa dengan tingkat pendidikan yang dicapai, responden tidak berkeberatan untuk makan laksa yang bisa jadi belum pernah mereka cicipi sebelumnya. Sedangkan keterkaitan antara daerah tempat tinggal dengan pengisi survei yang didominasi oleh mereka yang tinggal di Bogor adalah mayoritas pengunjung Laksa Cihideung berasal dari daerah Bogor juga. Ini menunjukkan keterikatan yang kuat antara masyarakatnya dengan makanan di daerahnya. Makanan lokal akan populer di antara lingkungan terdekatnya terlebih dahulu untuk kemudian menyebar ke lingkungan lainnya yang lebih jauh jaraknya dari lingkungan asalnya dan lebih majemuk. Kepopuleran ini bisa jadi terjadi akibat promosi dari penyantap Laksa Cihideung sebelumnya berkat WOM (Word of Mouth) atau promosi pihak lain seperti media.

\section{c. Keautentikan Laksa Cihideung}

Sebuah tempat makan sebagai destinasi wisata kuliner tidak akan berkembang tanpa adanya pengunjung. Sebaliknya, makanan bisa menjadi faktor penarik bagi pengunjung untuk mendatangi suatu daerah tujuan wisata. Seperti dikatakan oleh Martin \& Del Bosque (2008) bahwa kebutuhan merupakan langkah awal bagi seseorang dan bisa menjadi motivasi untuk melakukan sesuatu. Seperti saat mengunjungi suatu destinasi wisata. Makanan menjadi salah satu pendorongnya. Makanan bisa menjadi pull factor yang merupakan faktor eksternal. Makanan dapat menjadi salah satu aspek dalam destination specific attributes (Richardson \& Flucker, 2004).

Syarat menjadi aspek dalam destination specific attributes ini di antaranya adalah makanan yang autentik atau punya kekhasan.
Dikatakan oleh Abarca (2004) bahwa faktor autentik pada makanan lokal berakar pada soal budaya dan sosial ekonomi yang menggambarkan secara riil masyarakat yang diwakilinya. Faktor dari keauntentikan suatu makanan terdiri atas bahan dasar (ingredients), resep khas (methods), cara membuat (cooking style), dan cita rasa (taste). Lalu bagaimana kaitan antara Laksa Cihideung dengan responden pengisi kuesioner mengenai faktor autentik yang dapat dilihat berikut ini.

Dari bahan dasar Laksa Cihideung terlihat bahwa responden rata-rata mengatakan "setuju" atas atribut yang ditanyakan mengenai bahan dasar (ingredients) untuk membuat Laksa Cihideung. Bahan-bahan pembuat laksa terdiri atas oncom, taoge, kemangi, bihun, ketupat, tahu, serundeng, dan kuah santan berwarna kuning. Bahan yang khas pada Laksa Cihideung adalah penggunaan oncom dan kemangi. Kedua bahan tersebut lazim dan merupakan bahan makanan yang banyak terdapat di Bogor. Oncom merupakan makanan yang sangat populer di Jawa Barat. Oncom untuk Laksa Cihideung menggunakan oncom merah yang terbuat dari bungkil tahu yang setelah berfermentasi permukaannya akan ditumbuhi spora jamur yang berwarna merah. Oncom memiliki nilai dan mutu gizi yang baik akibat proses fermentasi, yatu membuat oncom lebih mudah dicerna dan dimanfaatkan oleh tubuh. Proses fermentasi jamur oncom ini juga membuat oncom dapat mencegah kembung. (Murdiati, 2013).

Selain oncom merah, bahan khas untuk Laksa Cihideung adalah kemangi. Kemangi atau yang dikenal sebagai srawung oleh masyarakat Bogor yang akan membuat Laksa Cihideung menjadi lebih beraroma harum. Selain memberi aroma yang wangi, kemangi juga berguna untuk kesehatan seperti khasiat antiseptik, mengurangi rasa sakit kepala saat sedang migrain, rasa sakit pencernaan, dan mengurangi insomnia. Laksa Cihideung sebagai representasi kekayaan bahan pangan daerah juga akan membuat petani lokal yang menghasilkan bahan-bahan pembuat laksa lebih bergairah karena hasil pertaniannya dibeli lebih banyak untuk mensuplai 


\section{TRANSPARANSI}

Jurnal Ilmiah Ilmu Administrasi

ISSN 2085-1162

wisatawan yang datang bersantap laksa. Efek simultan akan terjadi yaitu dengan membaiknya penghasilan petani berarti juga meningkatkan kesejahteraan daerah. Tak hanya untuk petani, tetapi juga untuk pedagang di pasar yang menjual bahan-bahan pembuat laksa serta sektor-sektor lainnya yang terkait dengan pertanian.

Untuk resep khas Laksa Cihideung, aspek autentik juga ditunjang dengan faktor resep khas (methods) yang bisa jadi berbeda-beda antara setiap pengolah masakan walaupun nama masakannya sama. Seperti pada Laksa Cihideung ini. Kuah Laksa Cihideung harus berwarna kuning, bahan pembuat kuahnya harus menggunakan kunyit dan temu manga, serta cara pengolahan kuah santan yaitu dengan merebusnya bersama tahu kuning. Kutipan wawancara dengan Ismi (29 tahun), responden adalah: "Favorit saya adalah tahu kuning yang direbus di dalam kuah laksa. Lembut dan tidak berbau kedelai. Ini karena tahu direbus dulu bersama kuah laksa sehingga menyerap bumbu di dalamnya."

Resep khas ternyata berkaitan dengan tradisi dan kebiasaan yang dilakukan oleh seseorang. Resep khas berkaitan dengan jumlah penggunaan bahan-bahan masakan serta urutan cara memasak. Berbeda jumlah penggunaan bahan-bahan masakan akam membuat penampilan masakan menjadi berbeda dalam soal warna, cita rasa, aroma, dan tekstur. Begitu pun dengan urutan cara memasak. Resep khas di Indonesia biasanya diturunkan dari ibu ke anaknya secara lisan. Ini berkaitan dengan tradisi budaya bangsa Indonesia yang merupakan budaya tutur bukan budaya tulisan (Murdijati, 2010). Berbeda dengan negara Barat yang terbiasa dengan tradisi tulis. Setiap resep khas yang ada sudah terdokumentasi dengan baik. Oleh karena itu sangat disayangkan jika resep-resep khas kuliner Indonesia yang mayoritas belum terdokumentasi dengan baik akan hilang karena kebiasaan soal tradisi lisan tersebut.

Adapun cara membuat Laksa Cihideung, terlihat bahwa responden "setuju" dan "sangat setuju" terhadap pertanyaan atas 3 atribut pertanyaa yang diajukan. Proses pembuatan
Volume 9, Nomor 02, September 2017

(cooking style) Laksa Cihideung sangat khas, yaitu dengan menggunakan kayu bakar dan cara menyeduh bihun, taoge, oncom, dan kemangi untuk membuat keempat bahan tersebut menjadi matang sebelum disajikan bersama bahan-bahan lainnya seperti ketupat, tahu, dan serundeng. Cara membuat merupakan aspek autentik dalam sebuah makanan tradisional seperti dikatakan oleh Hamzah (2013) bahwa keautentikan adalah sesuatu yang kompleks yang membutuhkan originalitas dan cara yang tradisional untuk membuat suatu makanan khas. Kayu bakar akan membuat cita rasa masakan beraroma harum kayu bakar sehingga membuat wisatawan menyukainya. Aroma kayu bakar itu akan terus tertinggal di dalam memori wisatawan dan pasa suatu hari bisa menjadi faktor penarik untuk berkunjung kembali ke Laksa Cihideung. Hal yang sama yang dikatakan oleh satu responden yang diwawancarai peneliti secara lebih lanjut bahwa cara merebus kuah laksa dengan kayu bakar membuat kuah beraroma smokey yang khas dan terdeteksi saat dicicipi.

Kutipan wawancara dengan Eksie (37 tahun), responden: "Suka dengan bau kayu bakar saat mencicipi laksa. Bahkan tetap terasa saat saya makan keesokan paginya untuk sarapan." Sedangkan proses penyeduhan bihun, taoge, oncom, dan kemangi untuk membuatnya menjadi matang sebelum ditaruh ke dalam piring saji bisa menjadi daya tarik tersendiri bagi Laksa Cihideung. Daya tarik ini merupakan faktor eksternal yang bisa dikembangkan untuk sarana promosi Laksa Cihideung.

Untuk cita rasa Laksa Cihideung, makanan yang autentik erat kaitannya dengan cita rasa yang spesifik. Responden "setuju" dengan 2 atribut pertanyaan yang diajukan mengenai cita rasa khas dari Laksa Cihideung. Cita rasa ini paling mudah terdeteksi langsung oleh wisatawan karena berhubungan dengan indera pencicip dan penciuman. Apa yang dirasakan saat mencicipi pertama kali itulah yang akan terekam oleh ingatan wisatawan. Cita rasa yang autentik dari suatu makanan merupakan 
Heni Pridia Rukmini Sari, Analisis Keautentikan dan Keunikan Laksa Cihideung Sebagai ...

hal yang sangat penting bagi pengunjung untuk mau datang dan menyantap makanan pada suatu tempat makan. Makanan dan sutu destinasi wisata sangat berhubungan erat. Seperti dikatakan oleh Lin (2006) bahwa suatu destinasi wisata yang berhubungan dengan makanan bisa dibagi menjadi wisata kuliner, wisata gastronomi, atau wisata makanan dengan definisi yang berbeda antara satu dengan lainnya. Cita rasa merupakan salah satu keunggulan dari Laksa Cihideung sehingga wisatawan mau untuk datang dan bersantap di warung laksa ini. Kualitas makanan yang ditunjukkan oleh item cita rasa menjadi pendorong responden untuk datang ke Laksa Cihideung.

Simpulan sementara yang diambil penulis adalah faktor autentik dapat diasosiasikan dengan penampilan makanan. Mulai dari bahan-bahan yang digunakan, cara pengolahan, hingga penyajian makanan saat akan disantap. Dikatakan oleh Hamzah (2013) bahwa cara paling mudah dan efektif untuk mencari tahu tentang keauntetikan suatu makanan adalah dengan menggunakan uji sensori. Penggunaan uji sensori akan membuat responden langsung merasakan dan melihat makanan yang mereka cicipi. Agar keauntetikan suatu makanan tetap terjaga tentu diperlukan campur tangan dengan pihak lain. Bukan hanya pemilik, dalam hal ini adalah Didin, tetapi juga stakeholder lainnya seperti pemerintah daerah setempat, media, atau lembaga swadaya masyarakat.

Menjadi destinasi wisata kuliner memang membutuhkan banyak elemen penunjang. Diperlukan elemen-elemen seperti attractions, public and private amenities, accessibility, human resources, image and character, serta price yang saling terkait satu sama lain (UNWTO, 2012). Daya tarik Laksa Cihideung yaitu cita rasa enak sudah menjadi satu elemen dari faktor attractions untuk bisa dijadikan sebagai destinasi wisata kuliner. Public and private amenities yang sudah ada dan menunjang Laksa Cihideung di antaranya adalah jalan raya mulus menuju lokasi Laksa Cihideung dan transportasi lokal yang memadai. Laksa Cihideung juga memiliki accessibility alias akses yang mudah dijangkau. Meski terletak $10 \mathrm{~km}$ dari pusat kota Bogor, lokasi Laksa Cihideung mudah dijangkau. Jika ingin bepergian dari luar kota Bogor, transportasi yang tersedia adalah dengan menggunakan kereta api atau bus yang kemudian diteruskan dengan angkutan lokal. Sedangkan untuk yang bepergian dengan kendaraan pribadi, lokasi Laksa Cihideung bisa ditempuh dengan melalui daerah Batutulis atau Ciawi.

Selain itu dibutuhkan juga tenaga kerja yang terlatih untuk melayani wisatawan di lokasi Laksa Cihideung yang didukung dengan keramahtamahan sehingga wisatawan merasa nyaman. Untuk itu diperlukan pelatihan dengan dukungan dari pemerintah setempat sehingga tenaga kerja yang ada di lokasi laksa Cihideung mengerti tentang dasar-dasar hospitality dalam industri pariwisata dan juga higienitas (kebersihan). Kekhasan dari Laksa Cihideung di antaranya penggunaan kayu sebagai bahan bakar bisa menjadi image and character yang menjadi ciri khas Laksa Cihideung. Selain itu, atraksi penyeduhan taoge, bihun, oncom, dan kemangi oleh penjualnya sebelum disajikan kepada pengunjung juga menjadi ciri khas penyajian Laksa Cihideung. Harga juga menjadi elemen pendukung yang akan mengundang wisatawan untuk datang bersantap. Seporsi Laksa Cihideung seharga Rp 9.000 membuat banyak wisatawan datang. Tak hanya untuk bersantap sendirian, tetapi juga datang berombongan bersama keluarga atau teman.

\section{d. Keunikan Laksa Cihideung}

Seperti dikatakan oleh Inskeep (1991) bahwa selain faktor keautentikan, setiap makanan juga mempunyai keunikan masingmasing. Keunikan tersebut terjadi karena aspek sejarah dan budaya yang melatarbelakangi munculnya makanan tersebut. Budaya merupakan hal dinamis yang merupakan hasil pengalaman seseorang atau suatu kelompok masyarakat (Caprio, et al., 2008). Makanan juga merupakan suatu identitas kebudayaan dan bisa dijadikan sebagai sarana untuk merawat suatu komunitas masyarakat. Proses pengolahan makanan ini bisa diperlakukan sebagai sarana untuk bersosialisasi. Makanan bukan hanya 


\section{TRANSPARANSI}

Jurnal Ilmiah Ilmu Administrasi

ISSN 2085-1162

sekadar hasil pengolahan dari bahan mentah menjadi sesuatu yang bisa dimakan. Makanan merupakan runtunan yang panjang mulai dari proses berproduksi hingga sampai di meja makan. Budaya sejak lama memang sudah menjadi salah satu faktor penting untuk mengetahui tentang konsumsi makanan. Goodenough mengatakan bahwa budaya juga dapat memperlihatkan karakteristik, sikap, tingkah laku, dan nilai-nilai yang dianut seseorang atau sekelompok masyarakat untuk melakukan sesuatu (1971).

Dari jawaban responden pada kuesioner yang dibagikan kepada responden mengenai keunikan Laksa Cihideung dilhat dari sejarah dan budaya ternyata mayoritas responden menjawab "setuju" untuk 5 atribut pertanyaan terutama pada pertanyaan "Laksa merupakan cerminan makanan khas Bogor". Hal ini bisa dilihat dari keauntetikan dari Laksa Cihideung, di antaranya adalah penggunaan kayu untuk memasak laksa, serta penggunaan oncom dan kemangi sebagai bahan dasar pembuat laksa. Dikatakan oleh Atkins \& Bowler (2001) karena budaya jugalah sebuah makanan bisa dikategorikan sebagai "acceptable" atau "unacceptable" atau "baik" dan "buruk". Dikatakan juga oleh Chang et al. (2010) bahwa selama berwisata, wisatawan akan mengonsumsi makanan yang bisa dibilang berbeda dari keseharian dan budaya mereka di rumah.

Makanan bisa menjadi salah satu faktor penarik dalam destinasi wisata. Makanan, dalam hal ini Laksa Cihideung, bisa dijadikan sebagai motivasi dari seorang wisatawan untuk bepergian mengunjungi suatu wilayah untuk berwisata kuliner. Seperti dituturkan oleh Voase (1995) bahwa konsep destinasi pariwisata sangat erat kaitannya dengan cita rasa (taste). Ada hubungan erat antara kuliner dan pariwisata. Setiap daerah mempunyai tingkat keunikan yang berbeda. Makanan yang unik bisa menjadi faktor menarik bagi wisatawan untuk mendatanginya ( $\mathrm{Au} \& \mathrm{Law}$, 2002). Bila telah menjadi destinasi wisata, lingkungan di sekitar Laksa Cihideung juga akan terangkat. Akan terjadi penyerapan tenaga kerja untuk tenaga-tenaga informal, seperti menjadi pelayan di warung Laksa Cihideung atau petugas parkir. Sektor ekonomi di daerah sekitar warung Laksa Cihideung akan juga bergerak. Misalnya, dengan dibukanya sentra oleh-oleh buah khas Bogor di seputar warung Laksa Cihideung.

\section{PENUTUP}

Dari hasil analisis dan pembahasan yang dilakukan diketahui bahwa keautentikan dan keunikan dari laksa Cihideung sebagai kuliner unggulan kota Bogor, yaitu Laksa Cihideung bisa menjadi destinasi wisata kuliner kota Bogor; Laksa Cihideung juga merupakan representasi kekayaan pangan daerah kota Bogor; Laksa Cihideung bisa menjadi kuliner unggulan kota Bogor; dan push factor dari Laksa Cihideung berdasarkan atas profil responden merupakan wisatawan Laksa Cihideung. Push factor tersebut adalah:

a. Berstatus sudah menikah dan berefek pada kebiasaan makan di luar.

b. Tingkat pendidikan tinggi (mulai dari D3 hingga S3). Tidak hanya sekadar untuk menuntaskan rasa lapar, tapi juga untuk menambah perbendaharaan soal cita rasa.

c. Faktor autentik dapat diasosiasikan dengan penampilan makanan. Mulai dari bahan-bahan yang digunakan, cara pengolahan, hingga penyajian makanan saat akan disantap. Faktor autentik ini akan membuat Laksa Cihideung mempunyai daya tarik sebagai destinasi wisata kuliner kota Bogor.

d. Budaya yang melatarbelakangi kemunculan laksa bisa menjadi sarana untuk mempromosikan makanan ini. Makanan merupakan runtunan panjang mulai dari proses berproduksi hingga sampai di meja makan.

Saran yang dapat dianjurkan untuk laksa Cihideung adalah:

a. Diperlukan dukungan dari seluruh stakeholder Laksa Cihideung selain pemiliknya, yaitu pemerintah daerah kota Bogor untuk membuat laksa Cihideung menjadi salah satu kuliner unggulan kota Bogor. Dukungan tersebut dapat berupa dukungan infrastruktur menuju lokasi 
Heni Pridia Rukmini Sari, Analisis Keautentikan dan Keunikan Laksa Cihideung Sebagai ...

Laksa Cihideung, dukungan amenitas seperti pembuatan toilet dan pelatihan soal kebersihan dan sanitasi, dan dukungan promosi. Dukungan lainnya bisa dari media, masyarakat sekitar, atau lembaga swadaya masyarakat.

b. Komposisi bahan laksa Cihideung adalah ketupat, bihun, taoge, oncom, kemangi, tahu, serundeng, telur rebus, dan kuah laksa. Laksa Cihideung bisa djadikan sebagai makanan alternatif untuk penganut vegetarian karena komposisi bahannya yang sebagian besar terdiri atas protein nabati.

\section{DAFTAR PUSTAKA}

Abarca, M.E. (2004). Authentic or Not, It's Original. Food \& Foodways 12. Hal. 125. USA: Taylor \& Francis.

Anonim. (2008). Dapur Naga, A Peek of Peranakan Cuisine. The Jakarta Post, Jakarta. Diakses pada 17 November 2014 dari situs resmi http://www.thejakartapost.com.

Anonim. (2014). Wisata Kuliner Masa Depan Industri Pariwisata. Banten. Diakses pada 23 Juni 2014 dari situs http:// pariwisata.rejanglebongkab.go.id/wisatakuliner-masa-depan-industri pariwisata.

Anonim. (2011). Worlds 50 Most Delicious Foods. Diakses pada 17 Februari 2015 dari situs www.CNN.com.

Au, N. \& Law, R. (2002). Categorical Classification of Tourism Dining. Annals of Tourism Research. 29(3), 819-823. Diakses pada 11 Juli 2015 dari www.Sciencedirect.com.

Blakey, C. (2012). Consuming Place: Tourism's Gastronomy Connection. University of Hawai'i at Hilo: Hawai'I College of HOHONU. Hal. 51-54.

Boyne, S., Williams, F., \& Hall, D. (2002). The Isle of Arran Taste Trail. London: Routledge.

Bryman, A. \& Teevan, J.J. (2005). Social Research Methods. Oxford: Oxford University Press.
Bromokusumo, A. (2013). Peranakan Tionghoa Dalam Kuliner Nusantara. Jakarta: PT Kompas Media Nusantara.

Cahyono, et al. (2015). Pengaruh Proporsi Santan dan Lama Pemanasan Terhadap Sifat Fisiko Kimia dan Organoleptik Bumbu Gado-Gado Instan. Jurnal Pangan dan Agroindustri Vol. 3 No 3. Hal. 10951106. Fakultas Teknologi Pangan, Universitas Brawijaya, Malang.

Chomeya, R. (2010). Quality of Psychology Test Between Likert Scale 5 and 6 Points. Journal of Social Sciences 6 (3): 399-403. Thailand: Mahasarakham University.

Du Rand, G. E. \& Heath, E. (2006). Towards a framework for food tourism as an element of destination marketing. Current Issues in Tourism. Hal. 9, 206-234.

Easton, V.J. \& Mc Coll, J.H. (1999). Statistics Glossary VII. Diakses dari http://www.stats.gla.ac.uk/steps/glossary/ basic definition.html.

Francois, Fortin. (1996). The Visual Food Encyclopedia. Kanada: Macmillan.

Gunawan, T. et al. (2014). Identifikasi Wisata Kuliner Kota Bogor. Bogor: Universitas Pakuan.

Hall, M. \& Mitchell, R. (2002). Tourism as a Force for Gastronomic Globalization and Localization. London: Routledge.

Hamzah, H, et al. (2013). Dimensions of Authenticity in Malay Cuisine from Experts' Perspective. Academic Journal of Interdisciplinary Studies Vol. 2 No. 3, Hal. 369. Rome: MCSER Publishing.

Hjalager, A.M., Richards, G. (2002). Tourism \& Gastronomy. London: Routledge.

Inskeep, E. (1991). Tourism Planning: An Integrated and Sustainable Development Approach. USA: Wiley.

Kothari, C.R. (2004). Research Methodology, Methods \& Techniques. New Delhi: New Age International (P) Ltd.

Kusmayadi. (2000). Metodologi Penelitian dalam Bidang Kepariwisataan. Jakarta: PT Gramedia Pustaka Utama. 
TRANSPARANSI

Jurnal Ilmiah Ilmu Administrasi

ISSN 2085-1162

Long, L. M. (2003). Culinary Tourism: A Folkloristic Perceptive on Eating Otherness: Southern Folklor. USA: University Press of Kentucky.

Lowenberg, M. E. (1970). Socio-cultural Basis of Food Habits. Food Technology: Hal. 24, 27-32.

Murdiati, A \& Amaliah. (2013). Panduan Penyiapan Pangan Sehat Untuk Semua. Jakarta: Prenamedia.

Murdijati. (2013). Bumbu, Penyedap, dan Penyerta Masakan Indonesia. Jakarta: PT Gramedia Pustaka Utama.

Nawawi, H. (1991). Metode Penelitian Bidang Sosial. Gajah Mada Universitas Press, Yogyakarta.

Nazir, M. (1999). Metodologi Penelitian. Jakarta: Ghalia Indonesia.

Okumus, B. et. al. (2007). Incorporating Local and International Cuisines In The Marketing of Tourism Destination. The Case of Hong Kong and Turkey. Tourism Management Vol. 28, Hal 253-261. Diakses pada 25 Maret 2015 lewat www.Sciencedirect.com.

Pendit, Nyoman S. (2002). Ilmu Pariwisata Sebuah Pengantar Perdana. Jakarta: PT Pradnya Paramita.

Pitana, I Gede \& Gayatri, Putu G. (2005). Sosiologi Pariwisata, Kajian Sosiologis Terhadap Struktur, Sistem dan Dampakdampak Pariwisata. Yogyakarta: Andi Offset.

Pitana, I Gede. \& Surya Diarta, I Ketut. (2009). Pengantar Ilmu Pariwisata. Yogyakarta: Andi Offset.

Rukmana, R. (2001). Kunyit. Kanisius, Yogyakarta.

Sevilla, C. G et al, (2007). Research Methods. Quezon City: Rex Printing Company.

Shields, P.M \& Tajalli, H. (2006). Intermediate Theory: The Missing Link to Successful Student Scholarship Journal of Public Affairs Education Vol 123.
Volume 9, Nomor 02, September 2017

Hal. 313-334. Diakses pada 5 Mei 2015 dari situs http://ecommons.txstate.edu/polsfacp/39 Local.

Spillane, J.J. (1994). Pariwisata Indonesia (Siasat Ekonomi dan Rekayasa Kebudayaan). Yogyakarta: Penerbit Kanisius.

Steinmetz, R. (2010). Food, Tourism and Destination Differentiation. The Case of Roturua, New Zealand. New Zealand: Auckland University of Technology.

Sudarmadji, S. (2003). Prosedur Analisa Bahan Makanan dan Pertanian. Yogyakarta: Liberty.

Verbeke, W. \& Lo'pez, G.P. (2005). Ethnic Food Attitudes and Behavior Among Belgians and Hispanics Living in Belgium. British Food Journal 107 (11), 823-840. Diakses pada 7 April 2015 dari www.emeraldinsight.com.

Wahab, S. (1976). Manajemen Kepariwisataan. Jakarta: PT Pradnya Paramita.

Weber, F. (2006). Natural Hazards: Increasing Challenges for Tourism Destination. Switzerland: University of Berne.

Winarno, B. (2013). 30 Indonesian Traditional Culinary Icons. Jakarta: Kementrian Pariwisata dan Ekonomi Kreatif.

Winarto, W.P. (2003). Khasiat dan Manfaat Kunyit. Jakarta: Agromedia Pustaka.

World Tourism Organization. (2012). Global Report on Food Tourism. Madrid: UNWTO.

Yoeti, Oka A. (1996). Pengantar Ilmu Pariwisata. Bandung: Angkasa.

Yuliana. (2008). Ciri-Ciri dan Kerusakan pada Tahu. Yogyakarta: Trubus Agriwidya. 